\title{
DETECTION OF Sclerotinia sclerotiorum ON SOYBEAN AND COMMON BEAN SEEDS BY MODIFIED NEON-S TEST
}

\author{
DETECÇÃO DE Sclerotinia sclerotiorum EM SEMENTES DE SOJA E DE FEIJÃO \\ PELA TÉCNICA NEON-S MODIFICADA
}

\author{
Roberto Resende dos SANTOS ${ }^{1}$; Tâmara Prado de MORAIS ${ }^{2}$ Fernando Cezar JULIATTI $^{3}$ \\ 1. Mestre em Fitopatologia - LAMIP- Laboratório de Micologia e Proteção de Plantas, Instituto de Ciências Agrárias - ICIAG, \\ Universidade Federal de Uberlândia - UFU, Uberlândia, MG, Brasil; 2. Pós Doutoranda UFU - CAPES, Uberlândia, MG, Brasil; 3. \\ Professor Titular, ICIAG - UFU, Pesquisador 1D do CNPq. juliatti@ufu.br
}

\begin{abstract}
The Neon-S method has been used for detection of Sclerotinia sclerotiorum on soybean and common bean seeds since the 2010 crop season. However, this method can lead to identification of false-positives due to the presence of other fungi that change the medium $\mathrm{pH}$. Thus, this study evaluated the effect of increasing incubation period on the reliability of Neon-S test in detecting S. sclerotiorum infection on soybean and common bean seeds. A randomized block design was set up with three replicates in a $3 \times 3$ factorial scheme, consisting of three detection methods (germination paper test, Neon-S, and modified Neon-S2) and three seed material (naturally infected common beans, naturally infected and artificially inoculated soybean seeds). The three methods were compared by evaluating 400 seeds per replication, after incubating them for seven days in Neon-S, for 15 days in Neon-S2, and for 30 days in germination paper, determining the presence of the fungus and of sclerotia adhered to the seeds. The data were submitted to the analysis of variance and the averages compared by the Tukey test at 5\% probability. From 2008 to 2012, 637 lots were evaluated. Among the seed material, artificially inoculated soybean presented the greatest pathogen infection index. The germination paper test led to $2.8 \%$ of positive samples, contrasting $29.7 \%$ of Neon-S. The modified method Neon-S2 increased detection sensitivity of S. sclerotiorum in seed lots (31.2\%); however, did not significantly differ from the Neon$\mathrm{S}$ method, despite its greater averages. We concluded that detection of S. sclerotiorum by the Neon-S method can be optimized by incubation for 15 days (Neon-S2), due to the formation of sclerotia near the infect seeds which confirms the presence of the pathogen avoiding false-positive results.
\end{abstract}

KEYWORDS: Glycine max. Phaseolus vulgaris. Sanity of seeds. White mold. Pathogen detection.

\section{INTRODUCTION}

The White mold disease, caused by the phytopathogen Sclerotinia sclerotiorum (Lib.) de Bary, is responsible for significant losses in agriculturally important crops worldwide. Yield losses vary depending on crop's susceptibility, climate conditions and disease management. In Brazil, the disease was first reported in potatoes in 1921 (CHAVES, 1964). S. sclerotiorum infects more than 70 botanical families, 270 genera and 400 plant species, such as common bean, soybean, sunflower, cotton, canola, potato, tomato, and lettuce (PAULA JÚNIOR et al., 2010). Especially concerning those crops, the disease has had negative economic impacts in the major and largest Brazilian agricultural regions (South, Southeast, and Middle West) (JULIATTI; JULIATTI, 2010).

There are currently no plant cultivars immune to the pathogen. Disease control is mainly done by chemical spraying, though often neglecting technical recommendations, which leads to reduction of control efficacy and yield loss (JULIATTI; JULIATTI, 2010; JACCOUD-FILHO et al., 2011). Central pivot fungigation is a practice that has been widely adopted in recent years and included for White mold management. However, the application of an excessive amount of fungicides to control the disease can generate unnecessary risks, both in the epidemiologic and environmental aspects.

The use of low quality seeds is a key factor in White mold dissemination, since those may be infected with the pathogen's dormant mycelium or concomitantly contaminated with sclerotia. Not only can the seed be a vehicle for pathogen transmission and primary inoculum, germination index and seedling vigor can be compromised (VIEIRA et al., 2001).

Long-distance dissemination of the pathogen through seeds is significant and worrisome. Sclerotia can be easily detected in seed lots, but when infection is by the mycelium, laboratorial analysis are required for correct diagnosis. Thus, the detection of the pathogen in seeds is of great importance, since seeds with high phytosanitary quality contribute to a lower use of chemicals throughout the crop cycle besides avoiding disease introduction or proliferation in the area. 
The criteria used for fungi detection in seeds generally follow the rules proposed by the International Seed Testing Association (ISTA, 2017), in which the microorganisms are stimulated to produce their structures or metabolites for proper identification. As to the fungus $S$. sclerotiorum, the visual observation of the presence of sclerotia follows the Rules of Seed Analysis (BRASIL, 2009a) where the blotter test is used for soybean, sunflower, cotton, common bean, and pea.

Despite known recommended methods, several studies have proposed modifications to standard protocols in order to minimize errors or problems, regarding the incubation period to evaluate the samples, the costs of analysis, and the risks to the operators in the handling of toxic chemical products. Alternative methods such as the modified germination paper test, the Neon-S test and the use of molecular techniques have shown potential for the safer and faster diagnosis of the pathogen.

Germination paper test has the inconvenience of being time-consuming. It demands one month of incubation prior to analyzing the results. During this prolonged time, seeds can be contaminated by bacteria or other fungi misinterpreting the analysis. The Neon-S test, on the other hand, contains an antibiotic (chloramphenicol) on medium composition that inhibits bacterial contamination, and a shorter incubation period (of only one week) that reduces the possibility of cross infection. In addition, the medium is supplemented with dichlorophenoxyacetic acid (2,4-D), to prevent dicots seeds from germinating, and a $\mathrm{pH}$ indicator. In the absence of $S$. sclerotiorum the medium is blue, turning yellow when the fungus is detected. However, the main disadvantage of this method is that other acid-producing fungi such as Rhizopus sp. and Aspergillus sp. can also modify the medium $\mathrm{pH}$ and, therefore, change its color (NAPOLEÃO et al., 2006). Thus, it is demanding the use of complementary techniques, such as microscopy, for correct pathogen identification. Besides, it would be interesting to avoid the use of 2,4-D in sample preparation since it is hazardous to humans and to the environment. The use of toxic chemical products may also be a threshold for this pathogen diagnosis by molecular techniques, along with the cost of the analysis.

The aim of this study was to ascertain whether increasing the incubation period enhances the reliability of the Neon-S test to detect $S$. sclerotiorum on soybean and common bean seeds, mainly by the formation of sclerotia associated to the medium color.

\section{MATERIAL AND METHODS}

From 2008 to 2012, 637 soybean and common bean seed samples/lots were evaluated at the Laboratory of Mycology and Plant Protection (LAMIP) from the Federal University of Uberlândia (UFU). The samples were obtained from the Triângulo Mineiro and Alto Paranaíba regions (Figure 1) and were naturally infected by the pathogen (positive or negative lots). The reports were separated by year, digitally filed, and annotations were made regarding the incidence of pathogens. Samples underwent sanitary tests capable of identifying the fungus $S$. sclerotiorum.

\begin{tabular}{|l|c|c|}
\hline \multirow{2}{*}{ Site } & \multicolumn{2}{|c|}{ Number of Samples } \\
\cline { 2 - 3 } & Common bean & Soybean \\
\hline Araguari & - & 06 \\
Ibiá & 15 & - \\
Patos de Minas & - & 395 \\
Uberlândia & - & 194 \\
Tupaciguara & - & 42 \\
\hline Total & & \\
\hline
\end{tabular}
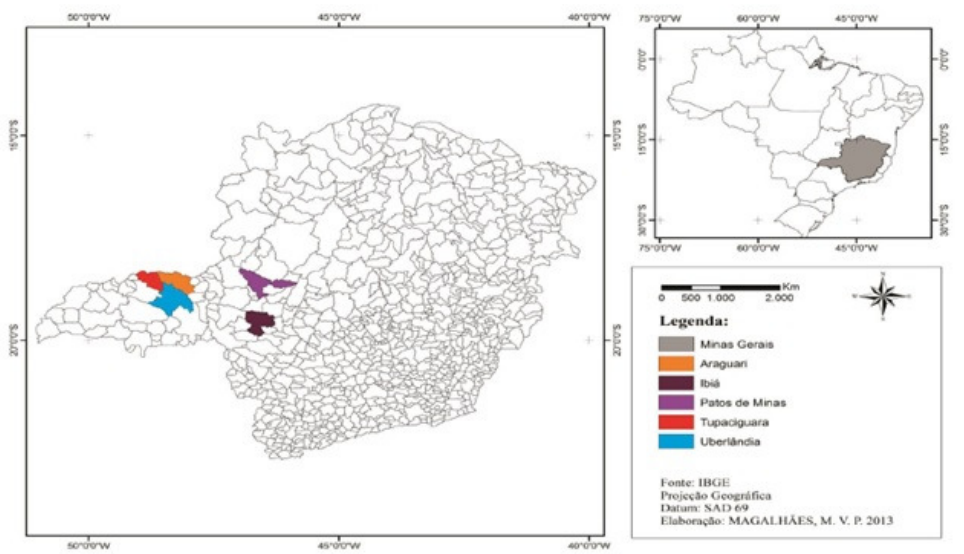

Figure 1. Total number of common bean and soybean seed samples evaluated from 2008 to 2012. Maps represent geographic location of the sites where samples were obtained.

-: no sample. 
In order to compare the methods for $S$. sclerotiorum detection, nine treatments were evaluated in a completely randomized block design set up in a $3 \times 3$ factorial arrangement with three replicates. The main factors were the seed material (common bean seeds naturally infected with White mold; soybean seeds also naturally infected; and soybean seeds cv. Nidera 7255 RR artificially inoculated with the pathogen) subjected to three detection methods (germination paper test, Neon-S, and Neon-S2). Seed samples were stored in a cold chamber $\left(4^{\circ} \mathrm{C}\right)$ until tests were performed.

Artificial infection of cv. Nidera 7255 RR was done with 7-day old fungus cultivated in PDA medium (Potato Dextrose Agar). Seeds were incubated with the pathogen in Petri dishes for 72 hours and later compared to the naturally infected seed lots. The detection methods evaluated in this study are detailed:

\section{Neon-S2 method}

Consists of a modification of the Neon-S method, altering incubation period from seven to 15 days. For samples' analysis, the seeds were previously frozen for 12 hours to reduce their metabolism and germination. This procedure was performed due to concerns on the health of the manipulator if using 2,4-D. The following reagents were used: $1000 \mathrm{~mL}$ of PDA $(200 \mathrm{~g}$ of potato in $1000 \mathrm{~mL}$ of distilled water, $20 \mathrm{~g}$ of dextrose and $15 \mathrm{~g}$ of agar) supplemented with $50 \mathrm{mg}$ of brome-phenol blue. The medium was autoclaved at $120^{\circ} \mathrm{C}$ for 15 minutes and cooled down $\left(\sim 50^{\circ} \mathrm{C}\right)$ before addition of $50 \mathrm{mg}$ of chloramphenicol. The medium was poured into $10-\mathrm{cm}$ diameter Petri dishes. Four hundred seeds were used per replicate and were randomly distributed in 20 Petri dishes. Incubation was done in the dark for 15 days at $20^{\circ} \mathrm{C}$. For the detection of the fungus, a yellow halo was observed around the seed, due to the presence of oxalic acid that changes the coloration of the brome-phenol blue into the yellow color, besides the formation of sclerotia, due to prolonged incubation period. This new way of interpretation is suggested for the elimination of false-positive results.

\section{Germination paper test}

This method uses two sheets of germination paper moistened with distilled sterile water in a volume equivalent to 2.5 times the weight of the dry paper. The seeds were wrapped with the paper and incubated in the dark for 30 days at $20^{\circ} \mathrm{C}$.

Four hundred seeds were used per replicate, which were randomly distributed in eight paper rolls containing 50 seeds each. For S. sclerotiorum detection, the formation of sclerotia was also observed. The 30-day incubation period is the threshold to conduct this method.

\section{Neon-S method}

The procedure of this method was the same as described in Neon-S2, but the evaluation was done seven days after incubation.

After collecting the data from naturally and artificially infected common bean and soybean seed lots, averages of the detection methods were compared by the Tukey test at 0.05 significance level using the statistical program Sisvar 5.3 (FERREIRA, 2011). Data were previously transformed by arc sen $\sqrt{ } \mathrm{x} / 100$.

\section{RESULTS AND DISCUSSION}

Table 1 shows the results of the $F$ test at 0.01 significance level. Significant interaction between seed material and detection method was observed. This implies that the best method to detect S. sclerotiorum depends on the seed material, including the type of infection. In other words, the choice of the method should consider if the seeds were naturally or artificially infected and if it is common bean or soybean.

Table 1. Analysis of variance on the incidence (\%) of Sclerotinia sclerotiorum on soybean (naturally and artificially infected seeds) and common bean (naturally infected seeds) subjected to three detection methods (germination paper test, Neon-S, and modified Neon-S2).

\begin{tabular}{lllll}
\hline SV & DF & SS & MS & F \\
\hline Block & 2 & 12.11 & 6.05 & $0.85^{\text {ns }}$ \\
Method & 2 & 190.64 & 95.32 & $14.07 * *$ \\
Seed material & 2 & $1,582.12$ & 791.06 & $116.75 * *$ \\
Method * Seed material & 4 & 295.21 & 73.80 & $10.89 * *$ \\
Error & 16 & 108.41 & 6.78 & \\
\hline
\end{tabular}

$\mathrm{CV}(\%)=39.15$

SV: source of variation; DF: degree of freedom; SS: sum of squares; MS: mean square; CV: coefficient of variation; ** and ${ }^{\text {ns: }}$ significant at $1 \%$ of probability and nonsignificant according to the F test, respectively. 
Averages of $S$. sclerotiorum incidence for all treatments are shown in Table 2. Significant differences among detection methods were verified by the Tukey test at 0.05 significance level. The treatment with inoculated soybean seeds and using the germination paper test led to inferior detection power compared to the other two methods, in which they showed higher incidence of the fungus. Although the Neon-S (seven days of incubation) and the Neon-S2 (15 days of incubation) did not present significant differences, the Neon-S2 method resulted in higher averages of pathogen incidence, indicating that extending the incubation period can increase the reliability of the method, since two weeks allow the identification of sclerotia in the seed lots. The presence of sclerotia next to the seeds confirms the infection and avoids false-positive results. Regarding both Neon detection methods, more infected samples were observed for the artificially inoculated soybean seeds, compared to naturally infected common bean and soybean samples (positive seed lots). This result may be because all seeds were inoculated and, therefore, the probability of occurrence of the disease in a larger amount of seed increased. Similar behavior was observed considering the germination paper test. Despite not differing from the naturally infected soybean seeds, higher averages of $S$. sclerotiorum were detected on the artificially inoculated soybean samples.

Table 2. Incidence (\%) of Sclerotinia sclerotiorum on common bean and soybean seeds detected by three methods.

\begin{tabular}{llll}
\hline & \multicolumn{2}{l}{ Method } & \\
\cline { 2 - 4 } Seed material $^{1}$ & Neon-S & Neon-S2 & Germination paper \\
\hline Naturally infected common bean & $0.00 \mathrm{aB}$ & $1.91 \mathrm{aB}$ & $0.00 \mathrm{aB}$ \\
Naturally infected soybean & $0.00 \mathrm{aB}$ & $3.26 \mathrm{aB}$ & $2.31 \mathrm{aAB}$ \\
Artificially inoculated soybean & $20.70 \mathrm{aA}$ & $24.13 \mathrm{aA}$ & $7.51 \mathrm{bA}$ \\
\hline
\end{tabular}

${ }^{1}$ averages followed by different letters, lowercase in each line and uppercase in each column, are statistically different by the Tukey test at $5 \%$ probability; data transformed by arc sen $\sqrt{ } \mathrm{x} / 100$.

No S. sclerotiorum infection could be detected on soybean samples by the germination paper test during 2008 (Table 3 and Figure 2). On the other hand, its presence was confirmed on soybean samples collected on 2009, 2010, 2011, and 2012, regardless of the method (Tables 3 and 5). Higher percentage of positive lots was obtained using the Neon-S and the modified Neon-S2 methods, including for pathogen detection on common bean seeds. The germination paper test resulted in $2.8 \%$ of positive samples while the Neon-S and the Neon-S2 methods detected infection on 29.7 and $31.2 \%$ of analyzed samples, respectively (Tables 3-6 and Figure 2). Another distinguishing factor among the analyzed lots was the percentage of infected and/or contaminated seeds, which varied from 0.25 to $21.75 \%$.

Table 3. Detection of the Sclerotinia sclerotiorum on soybean seeds by the germination paper test. Seed lots from 2008 and 2009.

\begin{tabular}{lllllllll}
\hline \multirow{2}{*}{ Soybean Cultivar } & \multicolumn{2}{l}{ Number of seed lots } & \multicolumn{2}{l}{$\begin{array}{l}\text { Number of positive } \\
\text { lots }\end{array}$} & $\begin{array}{l}\% \text { of } \\
\text { seeds }\end{array}$ & $\begin{array}{l}\text { infected } \\
\text { Correspondence } \\
\text { number of seeds }\end{array}$ & in \\
\cline { 2 - 8 } & 2008 & 2009 & 2008 & 2009 & 2008 & 2009 & 2008 & 2009 \\
\hline BRSMG 850G RR & - & 6 & - & 0 & - & 0 & - & 0 \\
BRSMG 750S RR & 4 & 11 & 0 & 0 & 0 & 0 & 0 & 0 \\
BRSMG 811C RR & - & 1 & - & 0 & - & 0 & - & 0 \\
BRSMG 810C & - & 1 & - & 0 & - & 0 & - & 0 \\
CD 237 RR & - & 2 & - & 0 & - & 0 & - & 0 \\
MG/BR 46 & - & 4 & - & 0 & - & 0 & - & 0 \\
BRS Favorita RR & 5 & 6 & 0 & 0 & 0 & 0 & 0 & 0 \\
L 8307 RR & 41 & - & 0 & - & 0 & - & 0 & - \\
M-Soy 6101 & 13 & 5 & 0 & 1 & 0 & 3.5 & 0 & 14 \\
M-Soy 7211 RR & - & 15 & - & 0 & - & 0 & - & 0 \\
M-Soy 7908 RR & 12 & 17 & 0 & 1 & 0 & 0.5 & 0 & 2 \\
M-Soy 8001 & - & 23 & - & 3 & - & 1.75 & - & 7 \\
M-Soy 8200 & 2 & 10 & 0 & 0 & 0 & 0 & 0 & 0
\end{tabular}




\begin{tabular}{lllllllll} 
M-Soy 9350 & 1 & - & 0 & - & 0 & - & 0 & - \\
NA 7255 RR & - & 1 & - & 0 & - & - & - & 0 \\
NA 8015 RR & - & 1 & - & 0 & - & - & - & 0 \\
NK 7074 RR & - & 4 & - & 1 & - & 9.5 & - & 38 \\
P984511 & 1 & - & 0 & - & 0 & - & 0 & - \\
RBL 8307 RR & - & 75 & - & 1 & - & 0.25 & - & 1 \\
BRS Sambaíba & - & 2 & - & 1 & - & 1.25 & - & 5 \\
BRS Valiosa RR & 24 & 22 & 0 & 1 & 0 & 1.25 & 0 & 5 \\
BRSMG 68 & 4 & 4 & 0 & 0 & 0 & 0 & 0 & 0 \\
\hline Total & 107 & 212 & 0 & 9 & - & - & 0 & 72 \\
\hline
\end{tabular}

Table 4. Detection of the Sclerotinia sclerotiorum on common bean seeds by the germination paper test. Seed lots from 2009.

\begin{tabular}{llllll}
\hline $\begin{array}{l}\text { Common bean } \\
\text { cultivar }\end{array}$ & $\begin{array}{l}\text { Number of seed } \\
\text { lots }\end{array}$ & $\begin{array}{l}\text { Number } \\
\text { positive lots }\end{array}$ & of $\%$ of infected seeds & $\begin{array}{l}\text { Correspondence in number } \\
\text { of seeds }\end{array}$ \\
\hline BRS Pérola & 10 & 0 & 0 & 0 \\
\hline Total & 10 & 0 & 0 & - & 0 \\
\hline
\end{tabular}

Table 5. Detection of the Sclerotinia sclerotiorum on soybean seeds by the Neon-S and Neon-S2 methods. Seed lots from 2010 to 2012.

\begin{tabular}{|c|c|c|c|c|c|c|c|c|c|c|c|c|}
\hline \multirow[t]{2}{*}{ Soybean cultivar } & \multicolumn{3}{|c|}{$\begin{array}{l}\text { Number of seed } \\
\text { lots }\end{array}$} & \multicolumn{3}{|c|}{$\begin{array}{l}\text { Number of positive } \\
\text { lots }\end{array}$} & \multicolumn{3}{|c|}{$\%$ of infected seeds } & \multicolumn{3}{|c|}{$\begin{array}{l}\text { Correspondence in } \\
\text { number of seeds }\end{array}$} \\
\hline & 2010 & 2011 & $2012^{*}$ & 2010 & 2011 & $2012^{*}$ & 2010 & 2011 & $2012^{*}$ & 2010 & 2011 & $2012^{*}$ \\
\hline NA 7337 RR & 2 & - & - & 1 & - & - & 0.25 & - & - & 1 & - & - \\
\hline ANTA 82 & 5 & - & - & 0 & - & - & 0 & - & - & 0 & - & - \\
\hline BRSMG 810C & 7 & 9 & - & 2 & 3 & - & 0.25 & 0.75 & - & 1 & 3 & - \\
\hline MG/BR 46 & 1 & - & - & 0 & - & - & 0 & - & - & 0 & - & - \\
\hline BRS Favorita RR & 8 & - & - & 2 & - & - & 1 & - & - & 4 & - & - \\
\hline L 8307 RR & 136 & - & - & 54 & - & - & 3.75 & - & - & 15 & - & - \\
\hline M-Soy 7211 RR & 9 & - & - & 3 & - & - & 1.5 & - & - & 6 & - & - \\
\hline M-Soy 7639 RR & 3 & - & - & 0 & - & - & 0 & - & - & 0 & - & - \\
\hline M-Soy 7908 RR & 7 & 7 & 5 & 4 & 0 & 1 & 0.75 & 0 & 0.25 & 3 & 0 & 1 \\
\hline M-Soy 8200 & 4 & - & - & 0 & - & - & 0 & - & - & 0 & - & - \\
\hline NA 7255 RR & 3 & 5 & 1 & 0 & 1 & 0 & 0 & 0.25 & 0 & 0 & 1 & 0 \\
\hline AN 8500 & 3 & 9 & - & 1 & 2 & - & 0.25 & 0.75 & - & 1 & 3 & - \\
\hline NS 7100 RR & - & - & 2 & - & - & 0 & - & - & 0 & - & - & 0 \\
\hline NS 8290 & - & - & 2 & - & - & 1 & - & - & 5.75 & - & - & 23 \\
\hline NT 12 & - & 3 & - & - & 0 & - & - & 0 & - & - & 0 & - \\
\hline NT 7001 & - & 1 & - & - & 0 & - & - & 0 & - & - & 0 & - \\
\hline RBR NT 12 & 6 & - & - & 2 & - & - & 0.25 & - & - & 1 & - & - \\
\hline BRS Valiosa RR & 23 & 10 & - & 0 & 5 & - & 0 & 1.25 & - & 0 & 5 & - \\
\hline Total & 217 & 44 & 10 & 69 & 11 & 2 & - & - & - & 32 & 12 & 24 \\
\hline
\end{tabular}

*Seed lots were analyzed using the Neon-S2 method.

Table 6. Detection of the Sclerotinia sclerotiorum on common bean seeds by the Neon-S and Neon-S2 methods. Seed lots from 2010 to 2012.

\begin{tabular}{|c|c|c|c|c|c|c|c|c|c|c|c|c|}
\hline \multirow{2}{*}{$\begin{array}{l}\text { Common } \\
\text { bean } \\
\text { cultivar }\end{array}$} & \multicolumn{3}{|c|}{ Number of seed lots } & \multicolumn{3}{|c|}{$\begin{array}{l}\text { Number of positive } \\
\text { lots }\end{array}$} & \multicolumn{3}{|c|}{$\%$ of infected seeds } & \multicolumn{3}{|c|}{$\begin{array}{l}\text { Correspondence } \\
\text { number of seeds }\end{array}$} \\
\hline & 2010 & 2011 & $2012^{*}$ & 2010 & 2011 & $2012^{*}$ & 2010 & 2011 & $2012^{*}$ & 2010 & 2011 & $2012^{*}$ \\
\hline BRS Estilo & - & - & 4 & - & - & 2 & - & - & 12.5 & - & - & 50 \\
\hline BRS Pérola & 5 & 10 & 18 & 0 & 2 & 6 & 0 & 15.25 & 21.75 & 0 & 61 & 87 \\
\hline Total & 5 & 10 & 22 & 0 & 2 & 8 & - & - & - & 0 & 61 & 137 \\
\hline
\end{tabular}

*Seed lots were analyzed using the Neon-S2 method. 


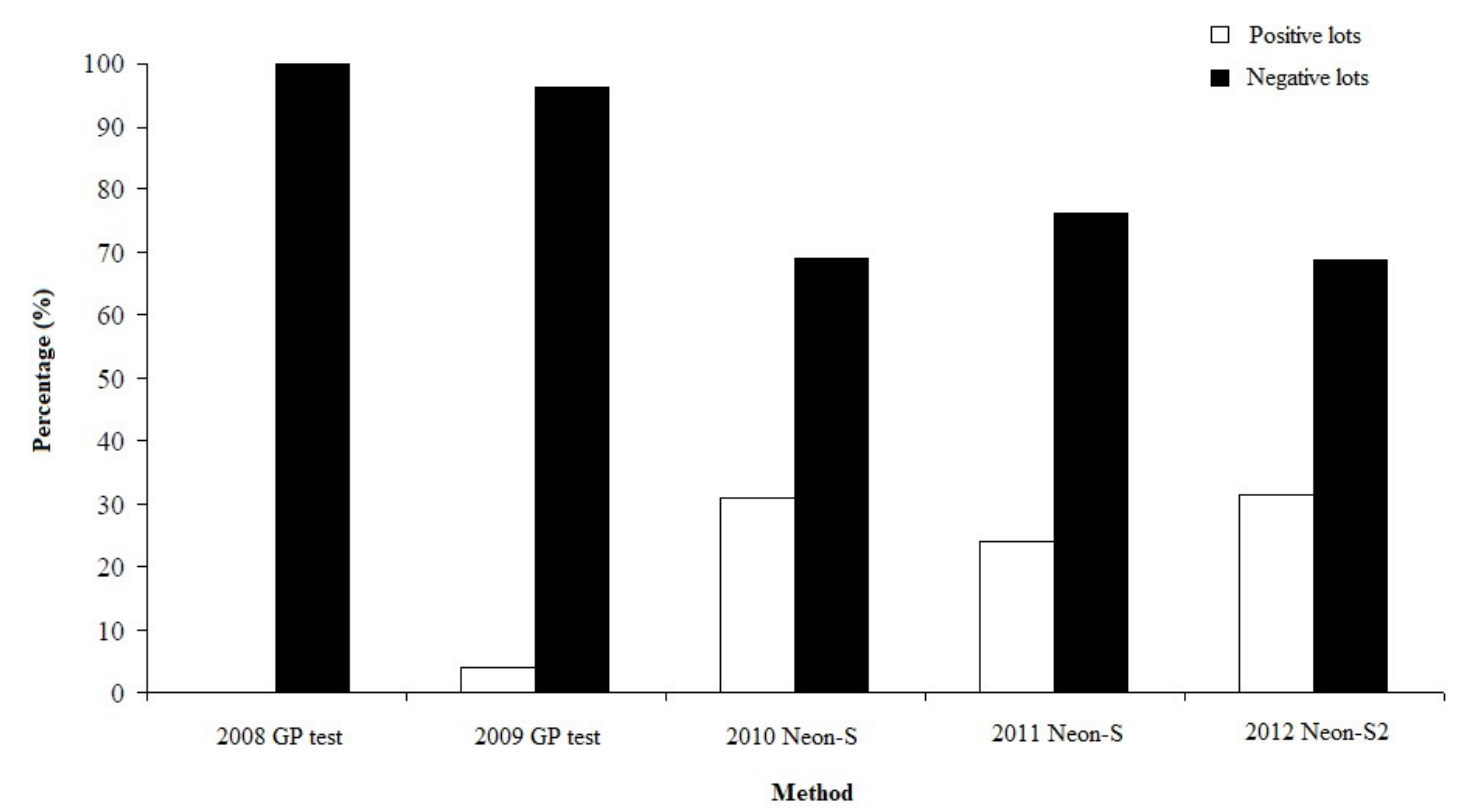

Figure 2. Percentage of seed lots contaminated with Sclerotinia sclerotiorum. Pathogen detection was accomplished by adoption of different methods on common bean and soybean samples collected from 2008 to 2012.

GP test: germination paper test.

Grabicoski (2012), with the objective of comparing methods of detection of $S$. sclerotiorum, analyzed three samples of soybean seeds from areas with history of incidence of White mold in the state of Paraná, through blotter test, germination paper and Neon-S. In sample I, 10 infected seeds were detected using the germination paper test. None of the other methods could detect the pathogen. In sample II, only one seed was contaminated according to the germination paper and blotter tests and three seeds by the Neon-S method. In sample III, more seeds were infected. The blotter test detected 45 seeds, the germination paper 112 and the Neon-S 15. It was observed that the germination paper test detected the presence of the pathogen in all samples and was the most efficient, differing from the results obtained in the present study where the modified Neon-S2 test was the most efficient. It is important to emphasize that in our study data was based on commercial seed lots sampled by the seed producer. In the work of Grabicoski (2012), the sampling was carried out in experimental fields, in the conditions of the region of the state of Paraná.

Henneberg et al. (2012), aiming to evaluate the efficiency of different methods to detect $S$. sclerotiorum on soybean seeds, carried out a research comparing five methods: the blotter test under three temperatures $\left(7,14\right.$ and $\left.20^{\circ} \mathrm{C}\right)$; germination paper test; and agar-brome-phenol medium (Neon-S). Regardless of the method, there was no relation between the percentage of pathogen incidence and its detection on seeds. The authors concluded that all the methods were efficient in detecting the fungus on artificially inoculated seeds. In addition, the methods did not differ significantly in the ability to detect $S$. sclerotiorum on seeds from areas with known natural incidence of the disease, as no relation between the incidence of the fungus in the field and its detection on the seeds was observed.

All methods compared in our study can overestimate the incidence of the fungus if it spreads from infected seeds to neighboring ones by contact (PARISI; PATRÍCIO; OLIVIERA, 2006), resulting in percentages of infection higher than $2 \%$ proportion generally found for common bean and soybean samples (PERES, 1996). The determination of a minimum distance between seeds could help alleviate this concern, though no research has focused on it. Despite the overestimation, the quantification of infected seeds is a good parameter to compare the methods.

When it comes to seed quality, the percentage of infection losses its importance and is substituted by the sensitivity of the method. The tolerance level of $S$. sclerotiorum in seed lots is based on the absence of sclerotia associated with the seeds (BRASIL, 2009b), since a single seed has the potential to jeopardize the crop's yield and contaminate the soil. This highlights the need for a methodology that detects the pathogen without misleading results. The proposal to increase the incubation period of the Neon-S test was to reduce the occurrence of false-negative samples by 
providing sufficient time for the formation of sclerotia.

The importance of the detection method relies on a better management strategy, such as the use of seed lots free from the pathogen or the employment of a more appropriate seed treatment including fungus-specific fungicides. Therefore, farmers will be able to choose the best chemical treatment and the best seed lot for each situation, avoiding future crop frustration or contamination of an area exempt from the pathogen and the disease.

\section{CONCLUSION}

The modification of the Neon-S method (altering incubation period to 15 days in order to favor sclerotia formation) led to a better reliability in the interpretation of results and elimination of false-positives. Therefore, the modified Neon-S2 method is more accurate and effective in detecting S. sclerotiorum on soybean and common bean commercial seed lots.

RESUMO: O método de Neon-S tem sido utilizado para a detecção de Sclerotinia sclerotiorum em sementes de soja e de feijão desde a safra de 2010. Porém, esse método possibilita a leitura de falsos-positivos devido ao aparecimento de fungos que também alteram o pH do meio. O objetivo deste trabalho foi verificar se o aumento do período de incubação melhora a confiabilidade do teste Neon-S em detectar o patógeno S. sclerotiorum em sementes de soja e de feijão. Utilizou-se o delineamento experimental de blocos casualizados, em esquema fatorial 3x3, sendo três métodos de detecção (rolo de papel, Neon-S e o meio modificado Neon-S2) e três tipos de sementes (feijão infectado naturalmente e sementes de soja infectadas natural ou artificialmente), totalizando nove tratamentos, com três repetições. Os três métodos foram comparados avaliando 400 sementes por repetição: em meio Neon-S com incubação de sete dias, Neon-S2 com incubação de 15 dias e em rolo de papel por 30 dias, anotando-se a presença do fungo e de escleródios aderidos às sementes. Realizou-se a análise de variância dos dados e teste de comparação de médias (Tukey 5\%). No período de 2008 a 2012 , 637 lotes foram testados. Dentre os tipos de sementes, a soja inoculada artificialmente apresentou os maiores índices de infecção pelo patógeno. O teste de rolo de papel apresentou 2,8\% de amostras positivas, enquanto o Neon-S $29,7 \%$. O método Neon-S2 aumentou a sensibilidade de detecção de S. sclerotiorum nos lotes de sementes analisadas (31,2\%); porém, não foi detectada diferença significativa comparativamente ao método Neon-S, ainda que com maiores médias. Conlui-se que a detecção de S. sclerotiorum pelo método Neon-S pode ser otimizada com a incubação por 15 dias (Neon$\mathrm{S} 2$ ), em virtude da formação de escleródios próximos às sementes infectadas, o que confirma a presença do patógeno e evita a leitura de falsos-positivos.

PALAVRAS-CHAVE: Glycine max. Phaseolus vulgaris. Sanidade de sementes. Mofo branco. Detecção de patógeno.

\section{REFERENCES}

BRASIL. Ministério da Agricultura, Pecuária e Abastecimento. Secretaria de Defesa Agropecuária. Regras para análise de sementes. Brasília: Mapa/ACS, 2009a. 399p.

. Portaria n ${ }^{\circ}$ 47, de 26 de fevereiro de 2009. Dispõe sobre a aprovação dos níveis de tolerância de pragas para Pragas Não Quarentenárias Regulamentadas. Diário Oficial, Brasília, 02 mar. 2009b. p.10-11.

CHAVES, G. M. Estudo sobre Sclerotinia sclerotiorum (Lib.) de Bary. Experientiae, Viçosa, v. 4, n. 2, p. 69$133,1964$.

FERREIRA, D. F. Sisvar: a computer statistical analysis system. Ciência e Agrotecnologia, Lavras, v. 35, n. 6, p. 1039-1042, 2011.

GRABICOSKI, Edilaine Mauricia Gelinski. Caracterização morfológica e patogênica de isolados de Sclerotinia sclerotiorum (Lib.) de Bary e detecção em sementes de soja. 2012. 138f. Dissertação (Mestrado em Agricultura), Universidade Estadual de Ponta Grossa, Ponta Grossa, 2012.

HENNEBERG, L.; GRZYBOWSKI, C. R. S.; JACCOUD-FILHO, D. S.; PANOBIANCO, M. Incidência de Sclerotinia sclerotiorum em sementes de soja e sensibilidade dos testes de detecção. Pesquisa Agropecuária Brasileira, Brasília, v. 47, n. 6, p. 763-768, 2012. https://doi.org/10.1590/S0100-204X2012000600005 
ISTA. International rules for seed testing. Zürichstr: The International Seed Testing Association, 2017. 296p.

JACCOUD-FILHO, D. S.; HENNEBERG, L.; GRABICOSKI, E. M. G.; VRISMAN, C. M.; PIERRE, M. L. C.; SARTORI, F. F.; CANTELE, M. Importância do mofo branco para a agricultura brasileira. In: SIMPÓSIO BRASILEIRO DE PATOLOGIA DE SEMENTES, 11., 2011, Ponta Grossa. Anais... Ponta Grossa:

Universidade Estadual de Ponta Grossa, 2011.

JULIATTI, F. C.; JULIATTI, F. C. Podridão branca da haste de soja: manejo e uso de fungicidas em busca da sustentabilidade nos sistemas de produção. Uberlândia: Gráfica Composer Editora, 2010. 35p.

NAPOLEÃO, R.; NASSER, L.; LOPES, C.; CAFÉ FILHO, A. Neon-S, novo meio para detecção de Sclerotinia sclerotiorum em sementes. Summa Phytopathologica, Botucatu, v. 32, n. 2, p. 180-186, 2006.

PARISI, J. J. D.; PATRÍCIO, F. R. A.; OLIVEIRA, S. H. F. Método do rolo de papel toalha modificado para a detecção de Sclerotinia sclerotiorum em sementes de feijão. Summa Phytopathologica, Botucatu, v. 32, n. 3 , p. 288-290, 2006.

PAULA JÚNIOR, T. J.; VIEIRA, R. F.; LOBO JÚNIOR, M.; MORANDI, M. A. B.; CARNEIRO, J. E. S. Mofo branco. In: DALLA PRIA, M.; SILVA, O. C. (Ed.). Cultura do feijão: doenças e controle. Ponta Grossa: Editora UEPG, 2010. p.101-105.

PERES, Ângela Pimenta. Detecção de Sclerotinia sclerotiorum (Lib.) de Bary em sementes de feijão (Phaseolus vulgaris L.) e soja (Glycine max (L.) Merrill): desenvolvimento de metodologias. 1996. $51 \mathrm{f}$. Dissertação (Mestrado em Fitopatologia). Universidade Federal de Lavras, Lavras, 1996.

VIEIRA, R. F.; PAULA JUNIOR, T. J.; PERES, Â. P.; MACHADO, J. C. Fungicidas aplicados via água de irrigação no controle do mofo branco no feijoeiro e incidência do patógeno na semente. Fitopatologia Brasileira, Brasília, v. 26, n. 4, p. 770-773, 2001. https://doi.org/10.1590/S0100-41582001000400015 